AGROLAND: The Agricultural Sciences Journal

Vol. 7, No. 2 December (2020), 91 - 98

P-ISSN : 2407- 7585 \& E-ISSN : 2407- 7593, Published by Tadulako University

\title{
EFFECTIVENESS OF GIBBERELLINS IN BREAKING DORMANCY OF SNAKEFRUIT SEEDS (SALACCA SNAKEFRUIT GEARTNER)
}

\author{
Enny Adelina ${ }^{1 *}$, Nuraeni $^{1}$, Yohanis Tambing $^{1}$, and Ida Musdalifa ${ }^{1}$ \\ ${ }^{1)}$ Faculty of Agriculture Tadulako University \\ Correspondence author's: Enny Adeliana \\ Email : ennyadelina@gmail.com
}

Submit: 1 December 2020, Revised: 6 December 2020, Accepted: December 2020

\begin{abstract}
This study aims to examine the effectiveness of gibberellins in breaking dormancy to produce high viability snakefruit (Salacca snakefruit Geartner) seeds. The materials used are snakefruit seeds from Tamareja Village, Donggala Regency, sterile sand media, aquades, and $\mathrm{GA}_{3}$ solution. This research was arranged using a completely randomized design (CRD) with one factor, namely the provision of gibberellin, consisting of five levels of concentration, namely $\mathrm{P} 0=$ control (without treatment), $\mathrm{P} 1=30 \mathrm{ppm}$ and $\mathrm{P} 2=40 \mathrm{ppm} \mathrm{P} 3=50 \mathrm{ppm} \mathrm{P} 4=60 \mathrm{ppm}$. each treatment was repeated five times so that there were 25 experimental units. Each experimental unit used 20 seeds. Observation data were analyzed using analysis of variance (ANOVA), followed by Tukey' HSD test if the treatment tested showed a significant effect. The results showed that gibberellin administration effectively broke snakefruit seeds' dormancy and produced seeds with high viability. The higher the gibberellins' concentration would increase germination speed plumule length, radicle length, and faster embryo axis emergence. Gibberellin $60 \mathrm{ppm}$ resulted in germination power 98\%, germination rate 20.97 days, plumule length $5.52 \mathrm{~cm}$, radicle length $5.15 \mathrm{~cm}$, and embryo axis emergence 9.2 days.
\end{abstract}

Keywords:, Embryo axis, Germination rate, Radicle, Viability, Plumule.

\section{INTRODUCTION}

Snakefruit (Salacca snakefruit Gaertner) is an essential national superior commodity that substantially increases the country's foreign exchange after mangosteen, pineapple, and banana commodities. China, Cambodia, and Malaysia are the three export destination countries for Indonesian snakefruit from 29 countries globally. The increase in snakefruit exports tends to increase significantly from year to year, even reaching $28 \%$ in 2018 (Indonesian Quarantine Hall, 2019). Snakefruit producing areas in Indonesia include the Sleman Regency, Yogyakarta, known as snakefruit Pondoh, DKI Jakarta with snakefruit Condet, North Sumatra with snakefruit Sidempuan, and Bali with snakefruit Bali.

Central Sulawesi Province has made snakefruit one of the leading regional commodities. However, its products have 
not been able to enter the export market because the fruits from Central Sulawesi have not met the required standards, namely quality, quantity, and product continuity. This is because snakefruit cultivation is generally cultivated in a yard or garden filler planted with other crops without effective management and maintenance. To answer the challenges and opportunities for export of snakefruit commodity, it is deemed necessary to improve the cultivation technology of snakefruit. One of the crucial aspects to be pursued is providing quality planting material through the technology of providing high-viability barking seeds. One of the problems in procuring quality snakefruit seeds is dormancy in the seeds, which results in slow germinating which results in the provision of seeds to be ready to be transferred to the field, which takes a relatively long time, reaching 6 to 8 months (Sukewijaya et al., 2009). Several previous studies regarding the breaking of snakefruit dormancy have been reported (Falastin, 2006) and (Kartikasari et al., 2019), which reported the use of $60 \mathrm{ppm}$ gibberellin could break snakefruit dormancy with\% germ germination, growth potential\%, and seed height $\mathrm{cm}$. However, the results of these studies do not explain how long it takes for the emergence of the embryo axis and the length of the seed plumule because the embryo axis is an important attribute in snakefruit germination as a starting place for the emergence of plumules and radicles and is an indicator of the viability of snakefruit seeds. Based on the description, the question that needs to be answered is whether giving Gibberellin is effective to break the dormancy of snakefruit seeds and at the same time produce high viability snakefruit seeds?

\section{MATERIALS AND METHODS}

\section{Study site and material used}

The research site was carried out at the Seed Laboratory, Faculty of Agriculture, Tadulako University, Palu from January to March 2019.
The tools used in this study were bean sprouts, oven, analytical scale, 1000 $\mathrm{ml}$ measuring cup, sprayer, scarification knife, sample envelope, and writing instruments. The materials used are snakefruit seeds from Tamareja Village, Donggala Regency, sterile sand media, aquades, and $\mathrm{GA}_{3}$ solution.

\section{Research design}

The design used in this study was a one-factor, completely randomized design (CRD), namely the provision of gibberellin, consisting of five levels of concentration, namely:

$\mathrm{P} 0=$ control (without treatment)

$\mathrm{P} 1=30 \mathrm{ppm}$

$\mathrm{P} 2=40 \mathrm{ppm}$

$\mathrm{P} 3=50 \mathrm{ppm}$

$\mathrm{P} 4=60 \mathrm{ppm}$

Each treatment was repeated five times so that there were 25 experimental units. Each experimental unit uses 20 seeds sown in one tub of sprouts (1 lot) to use 500 snakefruit seeds.

\section{Preparation of seeds and nursery media}

The seeds obtained from Tamareja Village come from healthy mother trees produced five times with good fruit quality, not defective, and uniform. The seeds come from physiologically ripe fruits characterized by brownish-black skin color and healthy. Extraction of seeds is done by separating the seeds from the fruit, then washing them clean and drying them.

The nursery media used was sterile sand, which was placed in plastic tubs measuring $35 \times 28 \times 10 \mathrm{~cm}$.

\section{Preparation of gibberellin solution}

The gibberellin in powder form is weighed (according to treatment), then put into a measuring cup and added with distilled water up to $1000 \mathrm{ml}$.

\section{Seed Scarification and Priming}

Snakefruit seeds that have been dried are scarified by cracking the seed's protruding surface (where the embryo axis exits) using a knife. Furthermore, the seeds were put into the $\mathrm{GA}_{3}$ solution (priming) according to the treatment for 18 hours. 


\section{Seeding Seeds}

After the snakefruit seeds primed at each concentration of $\mathrm{GA}_{3}$, the seeds were sown in a seedbed by placing the seeds horizontally with $2 \mathrm{~cm}$ in the sand medium. Each tub of sprouts contains 20 seeds.

\section{Maintenance}

Maintenance of seedlings is done by watering every morning and evening so that the nursery media's condition is maintained by humidity.

\section{Observation variable}

a. Germination (\%). The germination rate was calculated at 28 days after sowing based on the number of seeds germinated usually divided by the number of seeds germinated. The germination rate is calculated according to the formula:

$\mathrm{DB}=\frac{\text { Number of normal germinate }}{j \text { Number of seed germinated }} \times 100 \%$

b. Germination Rate (Average days). The germination rate measured by counting the seeds that normally germinated from the first day to the 28th day after sowing according to the formula:

Germination rate $=\frac{N 1 T 1+N 2 T 2+\cdots+N i T i}{\text { Total germinated seed }}$

Note:

$\mathrm{N}_{1,2 \ldots \mathrm{i}}$ : Number of germinated seed on 1 , 2 and on $\mathrm{i}$-th

$\mathrm{T}_{1,2 \ldots \mathrm{i}}$ : Day observation on 1,2 and on i-th

c. Plumula length $(\mathrm{cm})$. The plumules' length was measured at the end of the observation (28 days after sowing) by measuring the plumules starting from the root neck (base of the stem) to the point of growth.

d. Radicle length $(\mathrm{cm})$. The sprouts' length was measured at the end of the observation by measuring the radicle starting from the root neck to the end of the longest radicle.

e. The emergence of the embryo axis (days). The time for the emergence of the embryo axis was calculated based on the snakefruit seed embryo axis's initial appearance.

f. Sprout's dry weight (g). The sprouts' dry weight was measured at the end of the observation by drying snakefruit sprouts in an oven at $80^{\circ} \mathrm{C}$ for 16 hours and then weighing them to determine their weight.

\section{Data analysis}

Observation data were analyzed using variance analysis (ANOVA), and continued with Tukey's honestly significant difference (HSD) test if any significant effect among treatments.

\section{RESULTS AND DISCUSSION}

The analysis of the various percentage of snakefruit seed germination capacity showed that the treatment of various gibberellin concentrations had a significant effect on germination. The average germination rate is shown in Figure 1.

Figure 1 shows that the treatment of various gibberellin concentrations has a significant effect on the percentage of snakefruit seed germination. The highest percentage of germination was obtained at a concentration of $60 \mathrm{ppm}$, without gibberellin and $30 \mathrm{ppm}$, namely $95 \%$ and $96 \%$, not significantly different from the $50 \mathrm{ppm}$ concentration, namely $87 \%$, but significantly different from the concentration of $40 \mathrm{ppm}$, namely $83 \%$.

Analysis of the various germinating rates of snakefruit seeds showed that the treatment of various gibberellin concentrations significantly affected the germination rate. The average germination speed is shown in Figure 2.

The 5\% BNJ test in Figure 2 shows that the treatment of various gibberellin concentrations significantly affects the germinating speed of snakefruit seeds. The fastest germinating speed was obtained in the treatment of gibberellin concentration of 60 ppm, namely 20.97 days, not different from the concentration of $50 \mathrm{ppm}$, $30 \mathrm{ppm}$, and without gibberellin, but significantly different from the concentration of $40 \mathrm{ppm}$ treatment, namely the longest germinating was 22.94 days. 


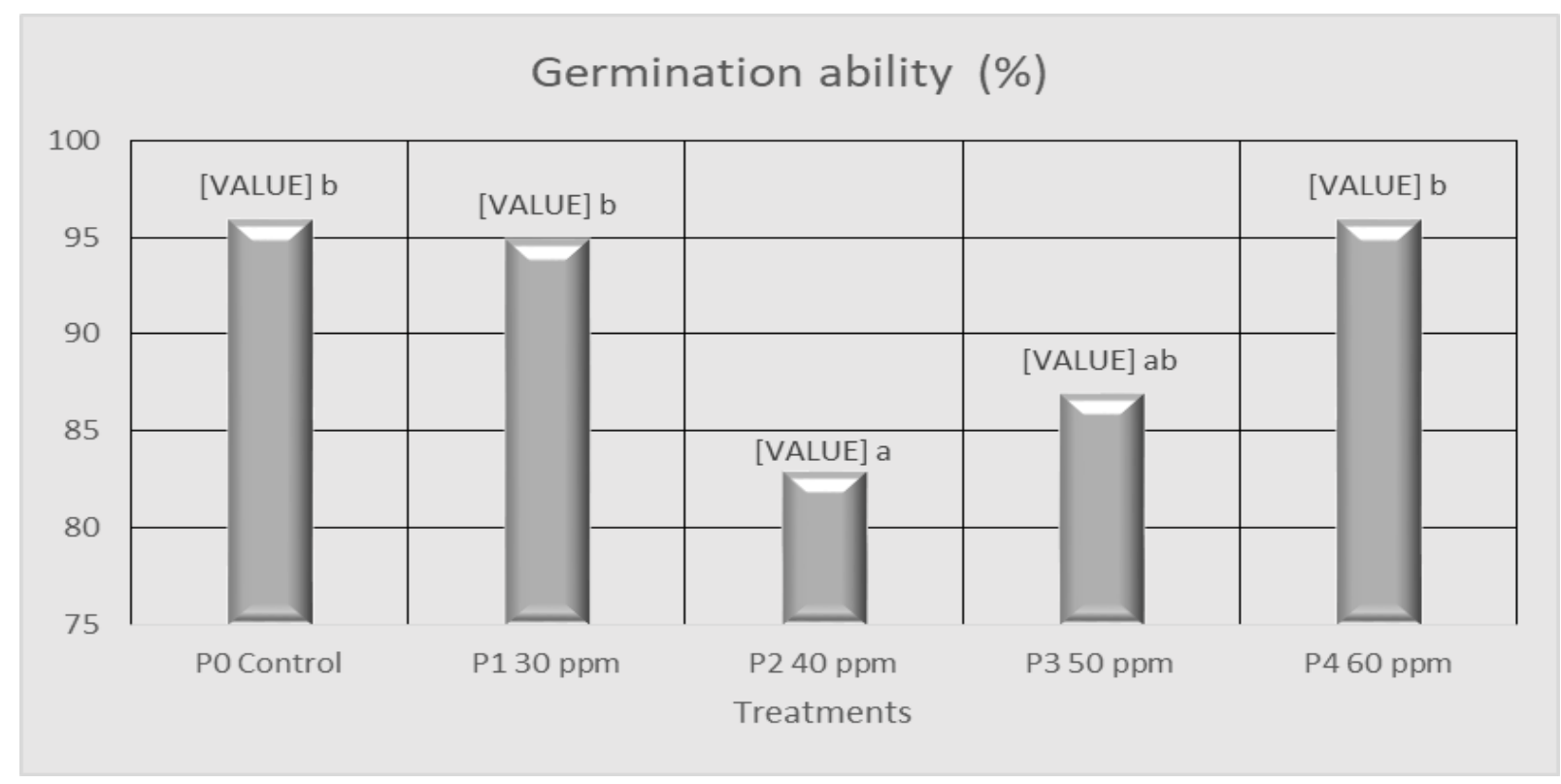

Figure 1. Average germination capacity of snakefruit seeds at various concentrations of gibberellin (\%). Note: Figures followed by the same notation $(\mathrm{a}, \mathrm{b})$ show no significant difference at the 5\% Tukey's HSD test.

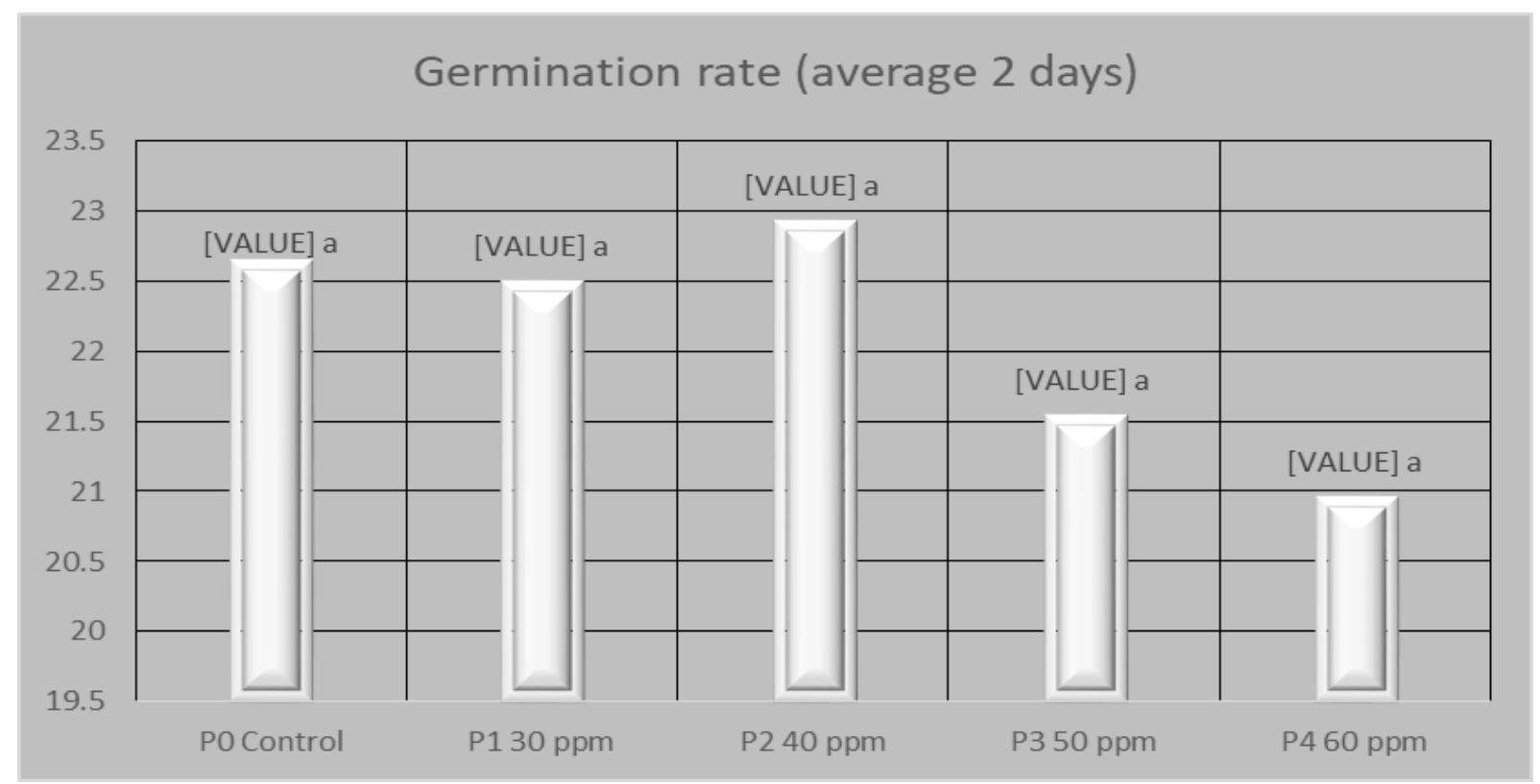

Figure 2. The average germinating speed of snakefruit seeds at various gibberellin concentrations (mean days).

Analysis of various lengths of snakefruit sprouts plumules showed that the treatment of various gibberellin concentrations had a significant effect on plumule length. The average length of the snakefruit seed sprouts is shown in Figure 3.

Figure 3 shows that the treatment of various gibberellin concentrations has a significantly different effect on the snakefruit seed plumules' length. The highest plumule length was obtained at a gibberellin concentration of $60 \mathrm{ppm}$, namely $5.52 \mathrm{~cm}$, not different from a concentration of $50 \mathrm{ppm}$, but significantly different than without gibberellin, a concentration of $30 \mathrm{ppm}$ and $40 \mathrm{ppm}$. 


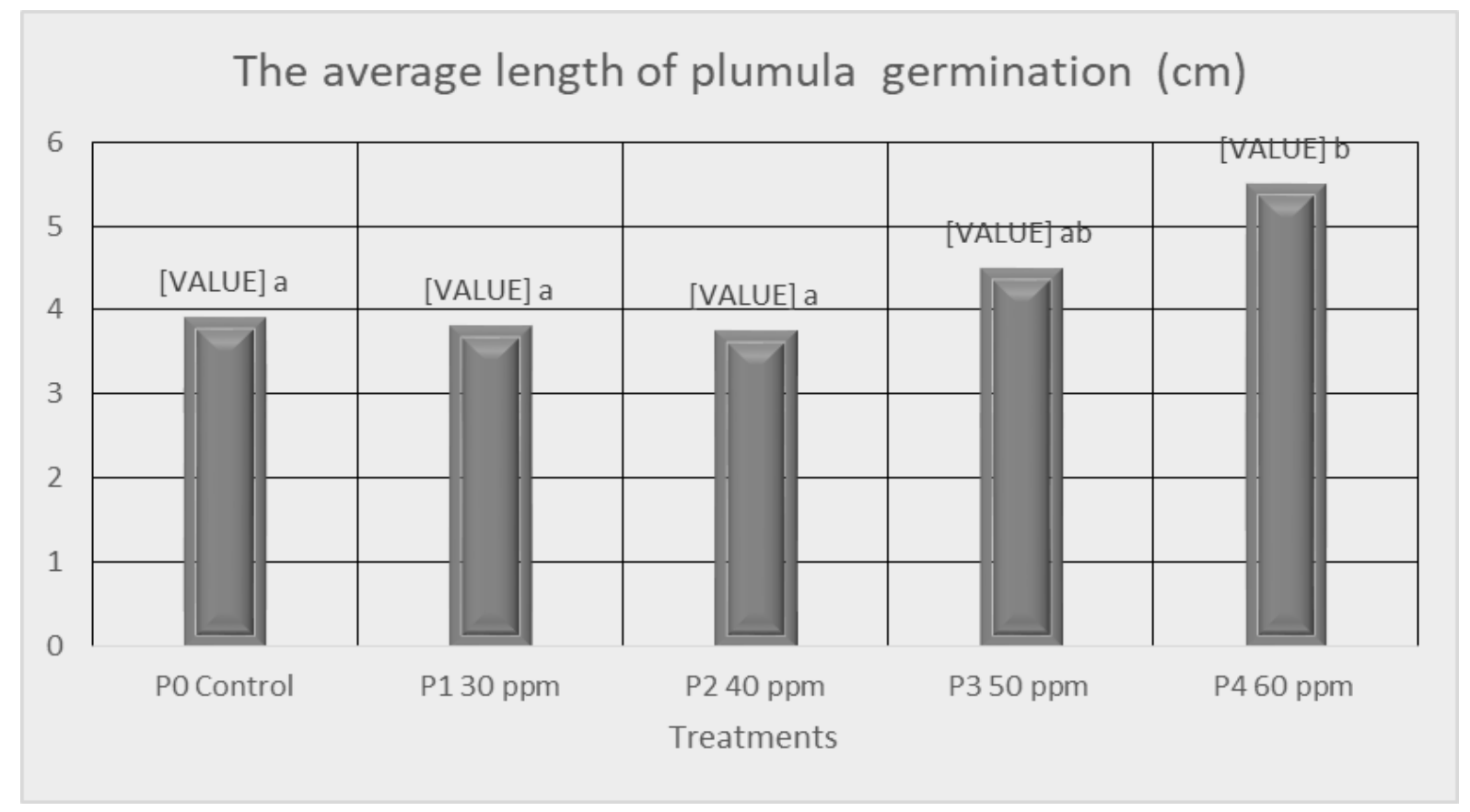

Figure 3. The average length of snakefruit seed plumules at various concentrations of gibberellin $(\mathrm{cm})$.

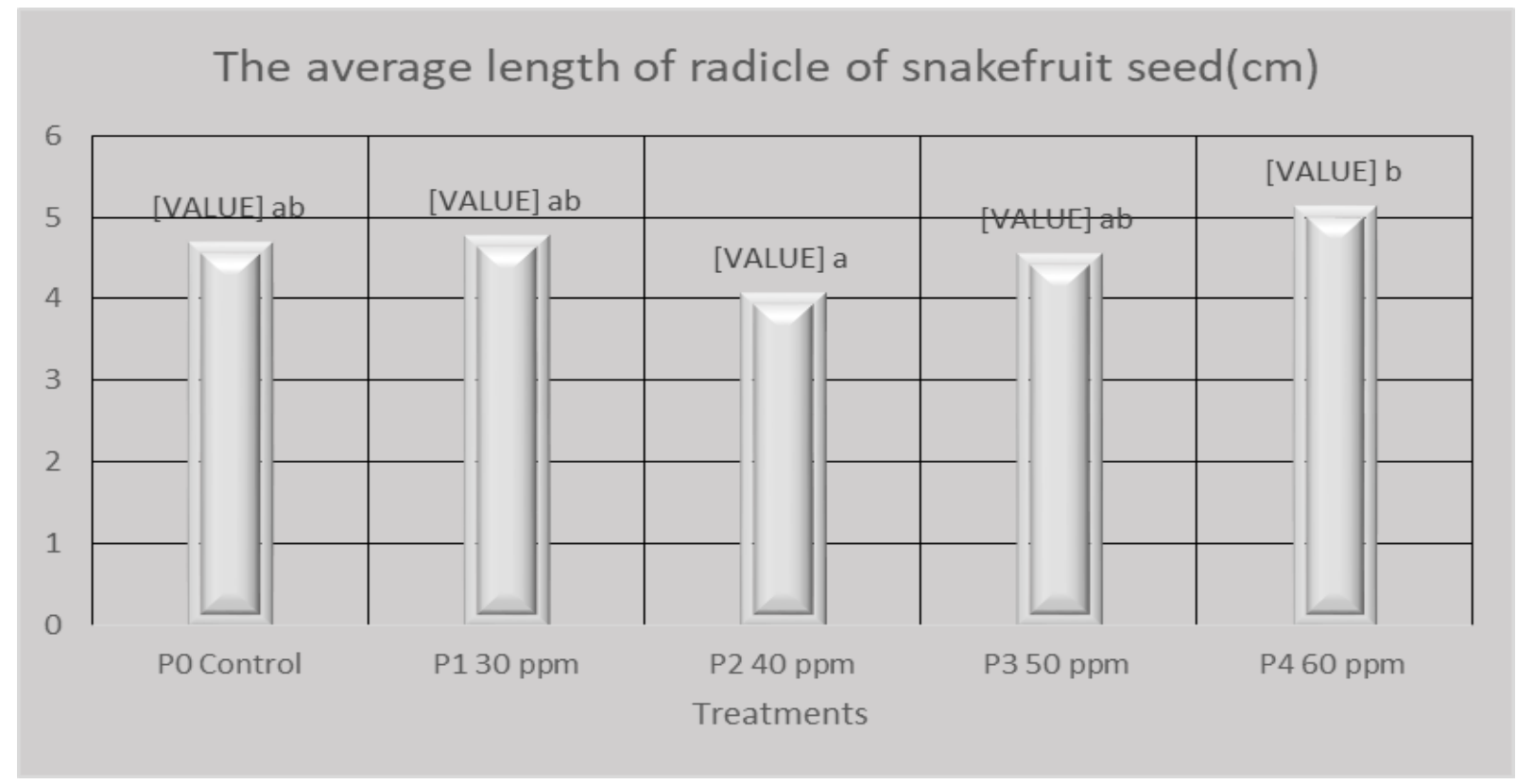

Figure 4. The average length of the radicle of snakefruit seeds at various concentrations of gibberellin $(\mathrm{cm})$.

The analysis of the length of the radicle sprouts of snakefruit seeds showed that the treatment of various gibberellin concentrations had a significant effect on the length of the radicle sprouts. The average length of the snakefruit seed sprouts is shown in Figure 4.
Figure 4 shows that the treatment of various gibberellin concentrations had significantly different effects on the radicle's average length. The most extended radicle length was obtained at a gibberellin concentration of $60 \mathrm{ppm}$, namely $5.15 \mathrm{~cm}$, not significantly different 
from 30 ppm, without gibberellin, a concentration of $50 \mathrm{ppm}$ but significantly different from a concentration of $40 \mathrm{ppm}$.

Analysis of various times of emergence of snakefruit seed embryo axes showed that treatment of various gibberellin concentrations had a significant effect on the time of emergence of the embryo axis. The average time for the emergence of the snakefruit seed embryo axis is shown in Figure 5.

Figure 5 shows that various treatments of gibberellin concentration on the time of emergence of the embryo axis have a significantly different effect. The emergence of the fastest embryo axis was obtained in the treatment of the gibberellin concentration of $60 \mathrm{ppm}$, namely 9.2 days, not significantly different from the concentrations of $30 \mathrm{ppm}, 40 \mathrm{ppm}$ and 50 ppm but significantly different than without giving gibberellin, namely it took 11.23 days to bring up the embryo axis no different from concentrations of $30 \mathrm{ppm}$ and $40 \mathrm{ppm}$.

Analysis of time variance of snakefruit seed dry weight showed that the treatment of various gibberellin concentrations significantly affected the dry weight of snakefruit seeds. The average dry weight of snakefruit seeds is shown in Figure 6.

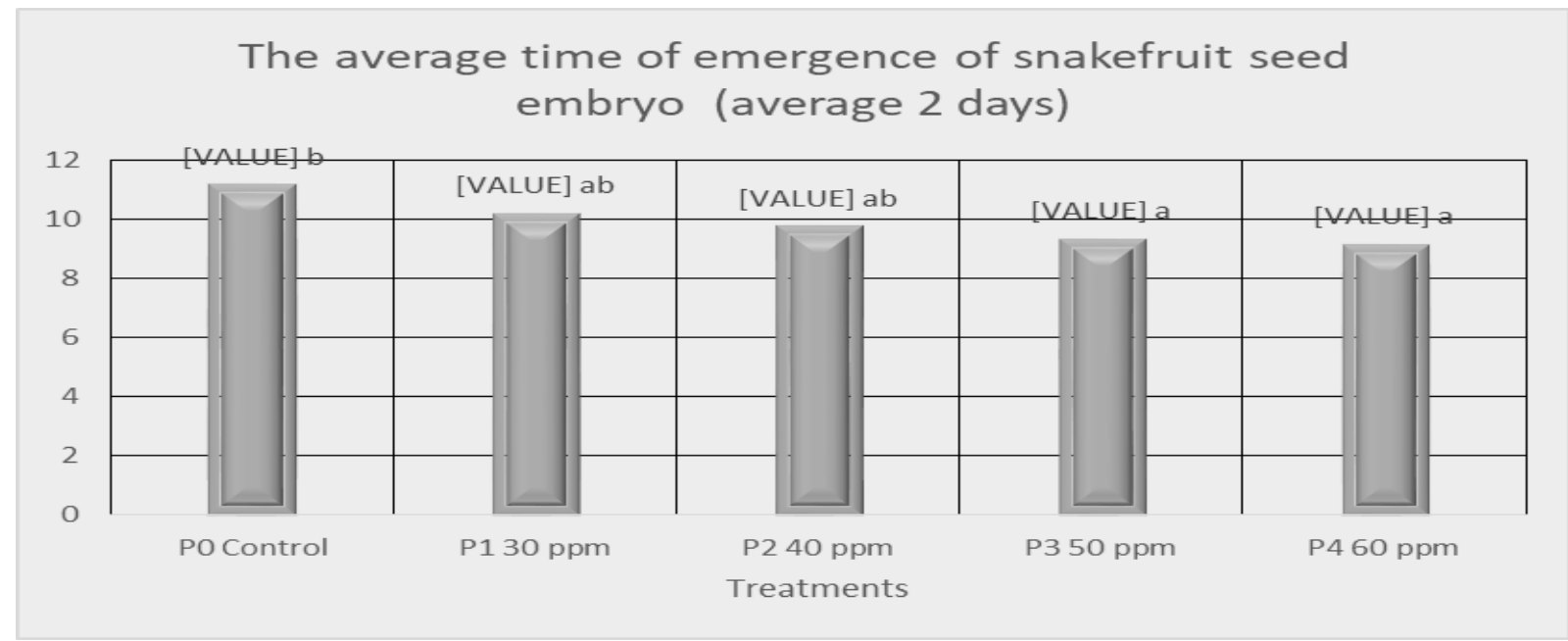

Figure 5. The mean time of the emergence of the snakefruit seed embryos at various concentrations of gibberellin (mean days).

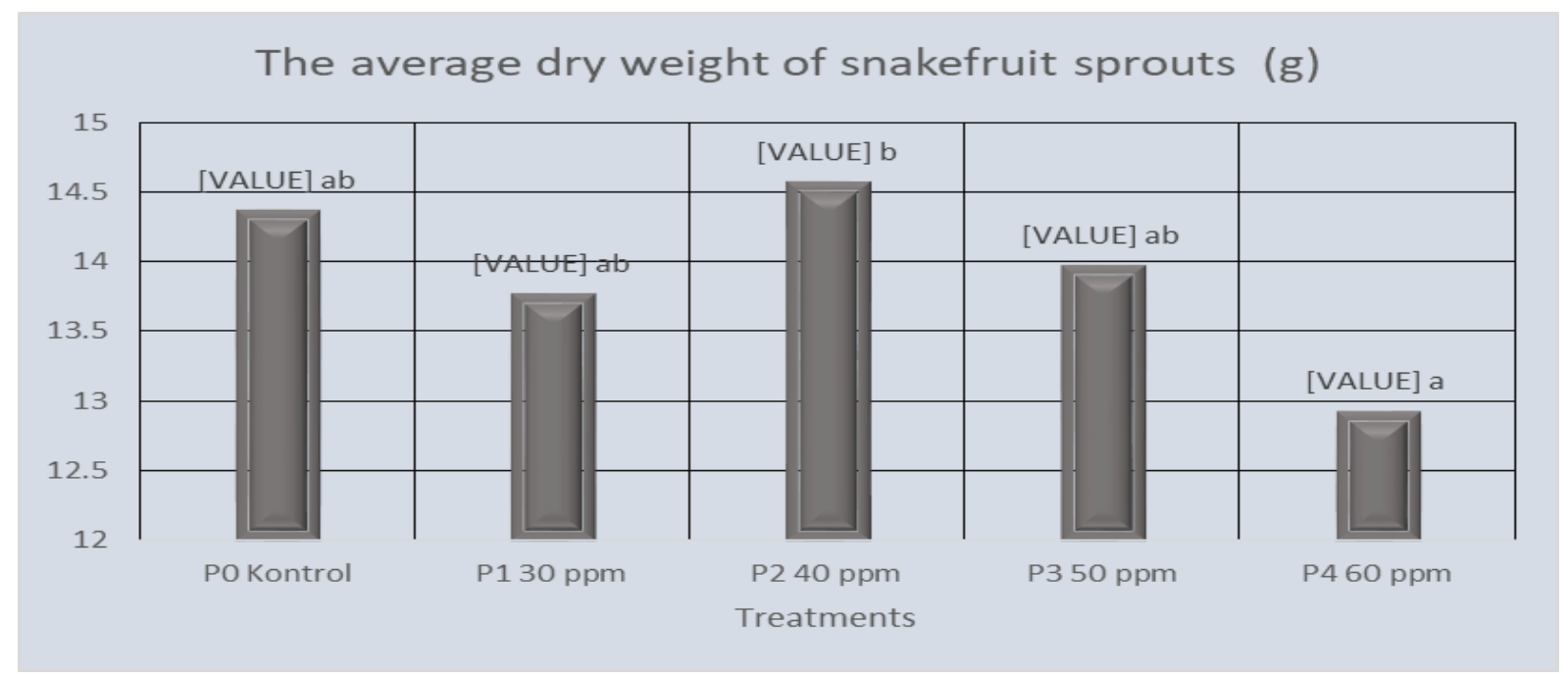

Figure 6 . The average dry weight of snakefruit sprouts at various concentrations of gibberellin (grams). 
The 5\% BNJ test in Figure 6 shows that the effect of various gibberellin concentrations has a significantly different effect on the dry weight of snakefruit seeds. The highest dry weight was obtained at a concentration of $40 \mathrm{ppm}$, namely 14.58 grams, significantly different from $60 \mathrm{ppm}$ treatment, but not significantly different from treatment without gibberellin, 30 ppm, and $50 \mathrm{ppm}$. The gibberellin concentration of $60 \mathrm{ppm}$ gave seed dry weight of 12.94 grams, which was not significantly different from the treatment without gibberellin, $30 \mathrm{ppm}, 50 \mathrm{ppm}$, and $60 \mathrm{ppm}$.

\section{Discussion}

The results showed that gibberellin was effective in breaking dormancy and at the same time increasing the viability of the seeds, namely germination, germination speed, plumule length, radicle length, and time required for the embryonic axis of the snakefruit seeds to emerge and grow. There is a tendency that the higher the concentration of gibberellin given will increase all the observed variables measured except for germination and dry weight. It can be assumed that the snakefruit seeds tested have good genetic characteristics (vigor) so that the seeds consistently display their special character even though the given environmental conditions are different, as it is known that high vigor seeds will be able to grow in optimum and sub-optimum conditions (Agurahe et al., 2019). Even so, addition of gibberellin concentrations up to $60 \mathrm{ppm}$ increases the rate of germination and the emergence of the embryo axis faster than other treatments. It indicates the high viability of snakefruit seeds can increase viability by giving gibberellins growth regulators at the optimum concentration. In this regard, gibberellin growth regulators' role can increase the length of oil palm seed plumules, but increasing the concentration of gibberellins from 100 ppm to $200 \mathrm{ppm}$ does not increase the length of plumules and radicles (Nuraini et al., 2016). The role of gibberellin in seed germination is to activate the cells surrounding the endosperm to form a number of hydrolytic enzymes such as amylase and protease, which will digest starch and amino acids as energy for growing cells. Amylase and protease enzymes also play a role in breaking down the seed membrane so that radicles and coleoptile can easily get out of the seed coat (Falastin, 2006). Gibberellins can accelerate dormancy breakdown because hydrolytic enzymes are activated to break down energy for the germination process (Agustin and Aprilianti., 2011). It was also stated that gibberellin plays a role in increasing tissue elongation, especially in the stem, resulting in a longer internal distance than plants without gibberellin treatment. The physiological mechanism that occurs is that gibberellin increases cell wall plasticity followed by hydrolysis of carbohydrates into sugar, thereby reducing cell potential. This allows water to enter the cell and causes cell elongation. Giving gibberellin at a low concentration will inhibit the enzyme activity so that the lower the gibberellin concentration will reduce the respiratory rate (Euis and Alfandi, 2013). Following this study's results, the low gibberellin concentration suppresses the rate of germination and emergence of the embryo axis.

Based on the research results, gibberellin's treatment at a concentration of $50 \mathrm{ppm}$ showed results that were not different from the concentration of gibberellin $60 \mathrm{ppm}$ at $4.52 \mathrm{~cm}$ long plumule emergence of the embryo axis was 9.38 days. This means that the gibberellin concentrations of $50 \mathrm{ppm}$ and $60 \mathrm{ppm}$ effectively break seed dormancy and produce high viability of snakefruit seeds, especially in the observed variables of plumule length and time of embryo axis emergence.

The germination phase of snakefruit seeds begins with the emergence of an embryonic axis as an important attribute of snakefruit sprouts (Palma plants in general) because the embryonic axis is where the plumules and radicles emerge. After reaching a certain length, the embryo's axis swells at the ends, and this is where the plumules and radicles appear (Rofik and Endang, 2008). 


\section{CONCLUSION}

Gibberellin at a concentration of 60 ppm is effective in breaking seed dormancy and increasing viability of snakefruit seeds with $96 \%$ germination, germination speed of 20.97 days, plumule length $5.52 \mathrm{~cm}$, radicle length $5.15 \mathrm{~cm}$, and embryo axis emergence time of 9.2 days.

\section{REFERENCES}

Agurahe, L., H. L. Rampe, and F. R. Mantiri. Pematahan dormansi benih pala (Myristica Fragrans Houtt.) menggunakan hormon giberalin. Pharmacon, 2019 8(1).

Agustin, E. K., and P. Aprilianti. 2011. Pengaruh Pemakaian Hormon Tumbuh $\mathrm{GA}_{3}$ (Giberelin Acid) terhadap Perkecambahan dan Pertumbuhan Biji Verschaffeltia splendida HA Wendl. Berk. Penel. Hayati Edisi Khusus, 2011 7:157160.

Euis, H., and Alfandi. Pengaruh Konsentrasi $\mathrm{GA}_{3}$ dan Lama Perendaman Benih terhadap. 2013.

Falastin, A. Pengaruh Giberelin $\left(\mathrm{GA}_{3}\right)$ Terhadap Viabilitas, Lama Waktu
Perkecambahan Dan Kecepatan Perkecambahan Biji Salak (Salacca edulis. 2006.

Kartikasari, S., Syaiful Anwar, and Florentina Kusmiyati. Viabilitas benih dan pertumbuhan bibit Salak (Salacca edulis Reinw) akibat konsentrasi dan lama perendaman giberelin $\left(\mathrm{GA}_{3}\right)$ yang berbeda. Jurnal Pertanian Tropik, 2019 6(3):448-457.

Nuraini, A., I. F. Pangaribuan, D. C. Suherman, J. Raya Bandung, and S. $\mathrm{Km}$. Dormancy Breaking of Oil Palm Seed by Dry Heat Treatment Method and Gibberellin. 2016.

Rofik, A., and M. Endang. Pengaruh perlakuan deoperkulasi benih dan media perkecambahan untuk meningkatkan viabilitas benih aren (Arenga pinnata (Wurmb.) Merr.). Jurnal Agronomi Indonesia (Indonesian Journal of Agronomy), 2008 36(1).

Sukewijaya, I. M., I. N. Rai, and M. S. Mahendra. Asian Journal of Food and Agro-Industry Development of salak bali as an organic fruit. As. J. Food Ag-Ind. 2009 37-43. 